\title{
Direct FuelCell/Turbine Power Plant
}

\author{
Semi-Annual Technical Progress Report \\ for \\ Period November 1, 2004 through April 30, 2005 \\ Hossein Ghezel-Ayagh \\ Principal Investigator
}

May 2005

DOE Grant No. DE-FC26-00NT40798

\author{
Prepared for: \\ U.S. Department of Energy \\ National Energy Technology Laboratory \\ P.O. Box 10940 \\ Pittsburgh, PA 15236-0940
}

Prepared by:

FuelCell Energy, Inc.

3 Great Pasture Road

Danbury, CT 06813 


\section{Disclaimer}

"This report was prepared as an account of work sponsored by an agency of the United States Government. Neither the United States Government nor any agency thereof, nor any of their employees, makes any warranty, express or implied, or assumes any legal liability or responsibility for the accuracy, completeness, or usefulness of any information, apparatus, product, or process disclosed, or represents that it's use would not infringe privately owned rights. Reference herein to any specific commercial product, process, or service by trade name, trademark, manufacturer, or otherwise does not necessarily constitute or imply its endorsement, recommendation, or favoring by the United States Government or any agency thereof. The views and opinions of authors expressed herein do not necessarily state or reflect those of the United States Government or any agency thereof." 


\section{ABSTRACT}

This report summarizes the progress made in development of Direct FuelCell/Turbine ${ }^{\circledR}$ $\left(\mathrm{DFC} / \mathrm{T}^{\circledR}\right)$ power plants for generation of clean power at very high efficiencies. The $\mathrm{DFC} / \mathrm{T}$ power system is based on an indirectly heated gas turbine to supplement fuel cell generated power. The DFC/T power generation concept extends the high efficiency of the fuel cell by utilizing the fuel cell's byproduct heat in a Brayton cycle. Features of the DFC/T system include: electrical efficiencies of up to $75 \%$ on natural gas, $60 \%$ on coal gas, minimal emissions, simplicity in design, direct reforming internal to the fuel cell, reduced carbon dioxide release to the environment, and potential cost competitiveness with existing combined cycle power plants.

Detailed design of the packaged sub-MW alpha DFC/T unit has been completed for mechanical and piping layouts and for structural drawings. Procurement activities continued with delivery of major equipment items. Fabrication of the packaged sub-MW alpha DFC/T unit has been initiated. Details of the process control philosophy were defined and control software programming was initiated. 
Contract No. DE-FC26-00NT40798

Technical Progress Report
Direct FuelCell/Turbine Power Plant November 1, 2004 through April 30, 2005

\section{Table of Contents}

1.0 Executive Summery

Page No.

$\begin{array}{lll}2.0 & \text { Experimental } & 1\end{array}$

2.1 Anode Booster Blower Performance Test 1

2.2 Recuperator Pressure Test 2

3.0 Results and Discussions 3

3.1 SubMW Power Plant Design 3

3.2 Process control software development 5

$\begin{array}{llr}4.0 & \text { Conclusion } & 8\end{array}$

$\begin{array}{lll}5.0 & \text { References } & 8\end{array}$ 


\subsection{EXECUTIVE SUMMARY}

FCE has successfully completed testing of the pre-alpha hybrid power plant. This firstof-a-kind power plant was constructed by integration of a $250 \mathrm{~kW}$ DFC stack with a 60 $\mathrm{kW}$ Capstone microturbine. The main objective of the tests was the development of the technologies that will lead to design of highly efficient and environmentally green power generation units using the existing natural gas infrastructure. Tests were conducted to develop the procedures for startup, normal operation, and shutdown of the hybrid power plant. The technology developed as a result of these proof-of-concept demonstration tests is being used in the design of sub-MW class DFC/T hybrid power generation units.

In this reporting period, two key milestones were accomplished: 1) Fabrication and packaging of the key equipment components for Alpha sub-MW DFC/T hybrid power plant was initiated. 2) The development of control software, including control philosophy documents, alarm lists and I/O list for the Alpha unit, was completed. The detailed design of the packaged sub-MW hybrid unit was completed for civil, mechanical, and piping disciplines. The set of piping and instrumentation diagrams (P\&IDs) was refined to incorporate software design parameters. Fabrication of the mechanical balance-ofplant was initiated. All major equipment items that have been received have been either installed or located on the fuel treatment skid. Power and control wiring, instrument panel, and breaker panel design layouts were initiated. Details of the process control philosophy were finalized and development of PLC control software programming was initiated.

\subsection{EXPERIMENTAL}

The experimental work consisted of the equipment checkout and acceptance tests before integration in the fuel cell power plant module.

\subsection{Anode Booster Blower Performance Test}

In the DFC/T hybrid power plant the Anode Booster Blower (ABB) is a critical piece of equipment. The $A B B$ is a high temperature blower used to control critical differential pressures around the fuel cell. The performance test for the ABB was run at the equipment manufacturer's site at the operating temperature of $1180^{\circ} \mathrm{F}$. Key operating parameters for the blower were tested and recorded. Figure 1 shows the test set-up for the blower performance test.

The test was set up as a closed loop system in order to minimize heating requirements and heat-up time for the test. The following parameters were monitored during the test:

- Blower inlet temperature

- Seal temperature

- Bearing temperatures

- Blower vibration

- Seal air flow 
- Pressure boost

- Fan speed

- Casing pressure

The tests results indicated that the blower successfully met the flow, temperature, and pressure requirements specified for the application.

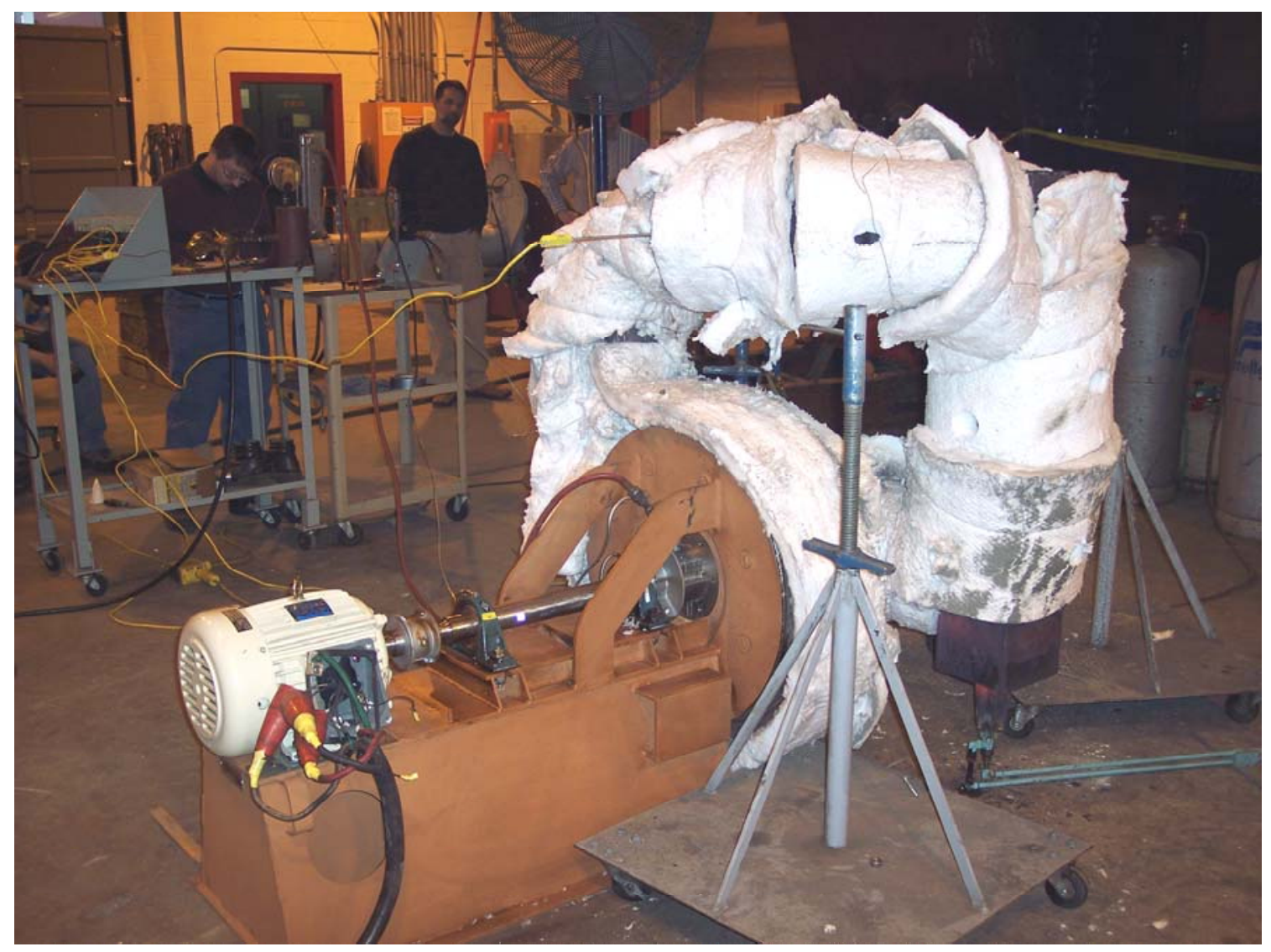

Figure 1. Anode Booster Blower Performance Test at the Factory

\subsection{Recuperator Pressure Tests}

The Fuel Preheater (FP) and the Low Temperature Recuperator (LTR) are two key pieces of equipment in the heat recovery system. They are located in the exhaust gas train and operate at high temperatures. Pressure tests for both units were conducted at the manufacturer's site. Tests were conducted at ambient temperatures. Test pressures were adjusted to compensate for actual operating temperatures. Figure 2 shows the Fuel Preheater during the pressure test. 
The Fuel Preheater and the Low Temperature Recuperator both successfully passed the pressure tests with no leaks between internal flow paths or to the external environment.

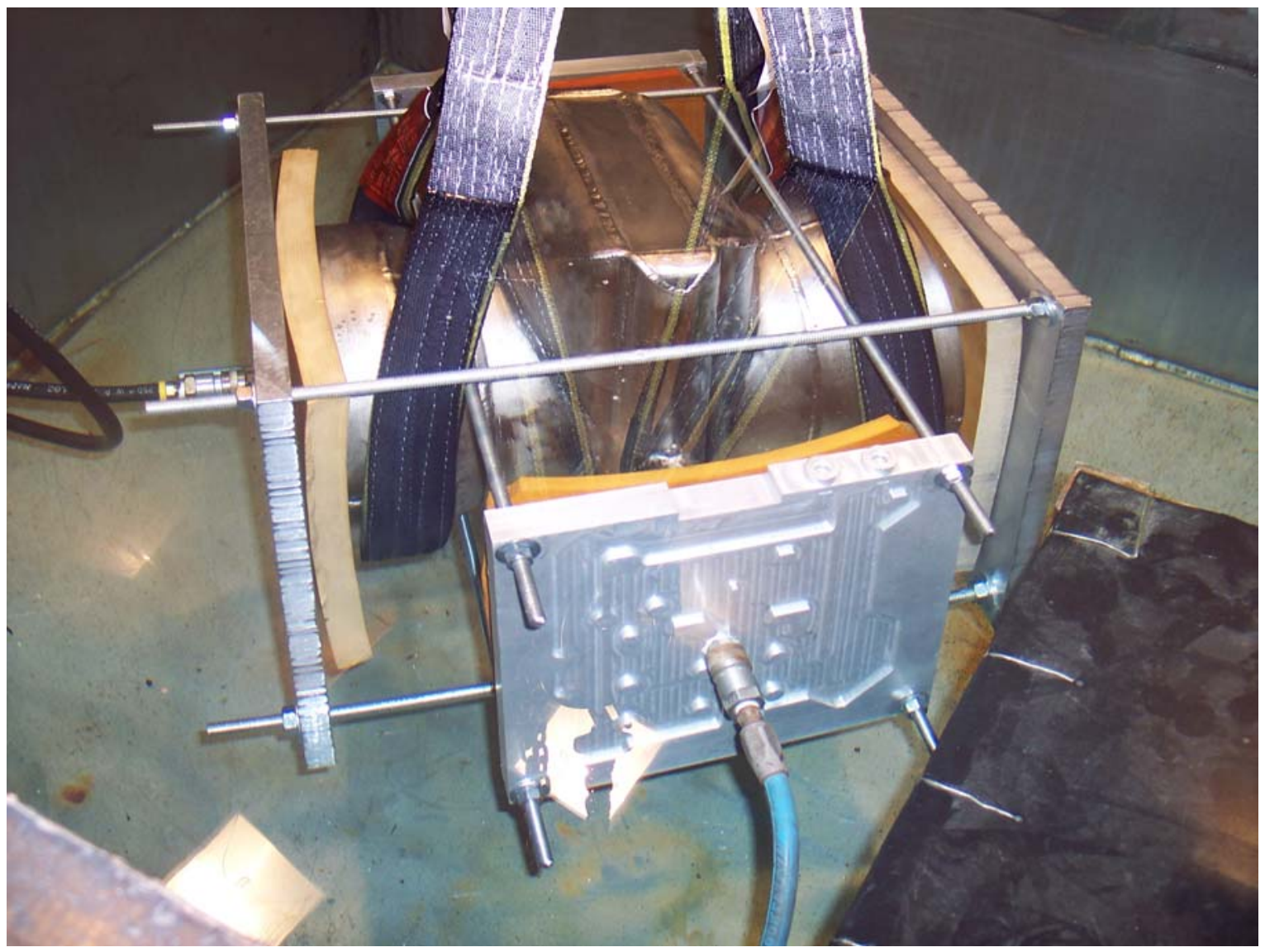

Figure 2. Fuel Preheater Pressure Test

\subsection{RESULTS AND DISCUSSIONS}

\subsection{Sub-MW Power Plant Design and Fabrication}

The design of the packaged sub-MW demonstration unit was continued. The design activities completed are listed below.

- The design modifications of the existing DFC300A fuel cell module for application to the DFC300/T system were tested. Major modifications included anode-exhaust pipe spool redesign to direct the anode stream to the balance-of-plant, and the cathode-in flow distributor for thermal uniformity of cathode-in gas to the stack. The anode-exhaust redesign was successfully tested in redirecting the flow direction of the anode exhaust stream. The cathode-in distributor was successfully tested, demonstrating uniform flow distribution and minimal pressure drop through the distributor. 
- The set of Piping and Instrumentation Diagrams (P\&IDs) was refined to incorporate design information and recommendations resulting from software development and coding.

- All equipment items have been ordered, and the majority of the equipment has been received. Items that have been received have been installed or located on the fuel treatment skid.

- Detail design of the civil, mechanical, and piping is complete. Three-dimensional drawings have been generated and issued for the disciplines referenced above. Civil design included the fuel treatment skid, the fuel cell skid, and the equipment supports. Mechanical design includes the general arrangement of all the equipment. Piping design included the piping spools, supports, expansion joints, and pipe specialty items.

- Fabrication is proceeding with the following items completed: fuel treatment skid structural steel, fuel cell skid structural steel, equipment supports, pipe spool fabrication, and pipe supports. Pipe installation was initiated. Insulation of installed equipment and pipe was initiated.

- Vendor bids for all valves, transmitters, thermocouples, flow elements, safety valves, pressure regulators, etc., were evaluated. All key instrument and control equipment have been ordered and received from suppliers. Valve and instrument installation has been initiated in conjunction with piping installation.

- Electrical power distribution design has been completed. Fabrication of the instrument control panels was initiated. Electrical checkout of valves was initiated.

Figure 3 below shows the fabrication of the fuel treatment skid with installation of equipment, piping, insulation, etc., progressing. 


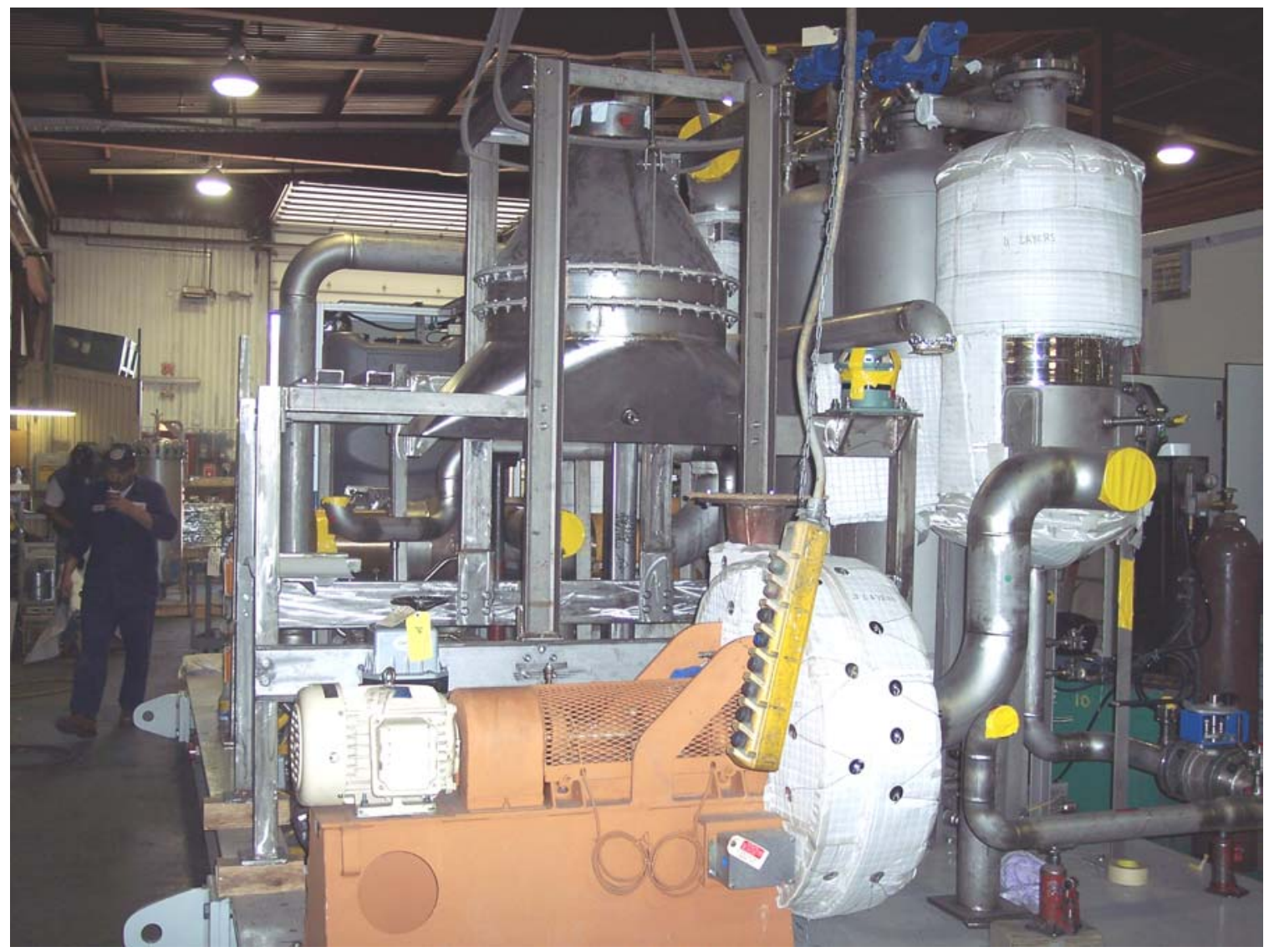

Figure 3. Fuel Treatment Skid Fabrication

\subsection{Process control software development}

Process control software development including fuel cell process control philosophy, alarm lists, I/O lists, and incorporation of the microturbine control philosophy into the overall hybrid fuel cell system philosophy were completed.

The control software development is comprised of the following key activities:

1. Control philosophy: The details of the microturbine start-up, the stack differential pressure and anode booster-blower control, and start-up strategies were developed. The control strategies for control of air, water, and fuel were also developed based on the DFC300 power plant control system.

2. Alarm list: The alarm list and proper alarming actions were developed based on the P\&ID and the DFC300 power plant. 
3. PLC programming of ladder logic in VersaPro: The control philosophy, alarm list, as well as associated permissives and interlocks were programmed in PLC ladder logic.

4. HMI programming: Programming of the HMI screens has been completed. A commercial software package, Cimplicity, is used to develop the display screens. A total of 41 screens including power plant setup, grid setup, monitoring, P\&IDs, trends, and controllers have been created. The HMI screens for the "DFC Module", "Fuel Preparation" and "Turbine" are shown in the Figures 4,5 and 6 respectively.

5. Test/Simulate PLC and HMI programs: Debugging of the software has been initiated.

6. Process control software acceptance test plan: The test plan is based on the procedures developed for the commercial DFC300 power plants.

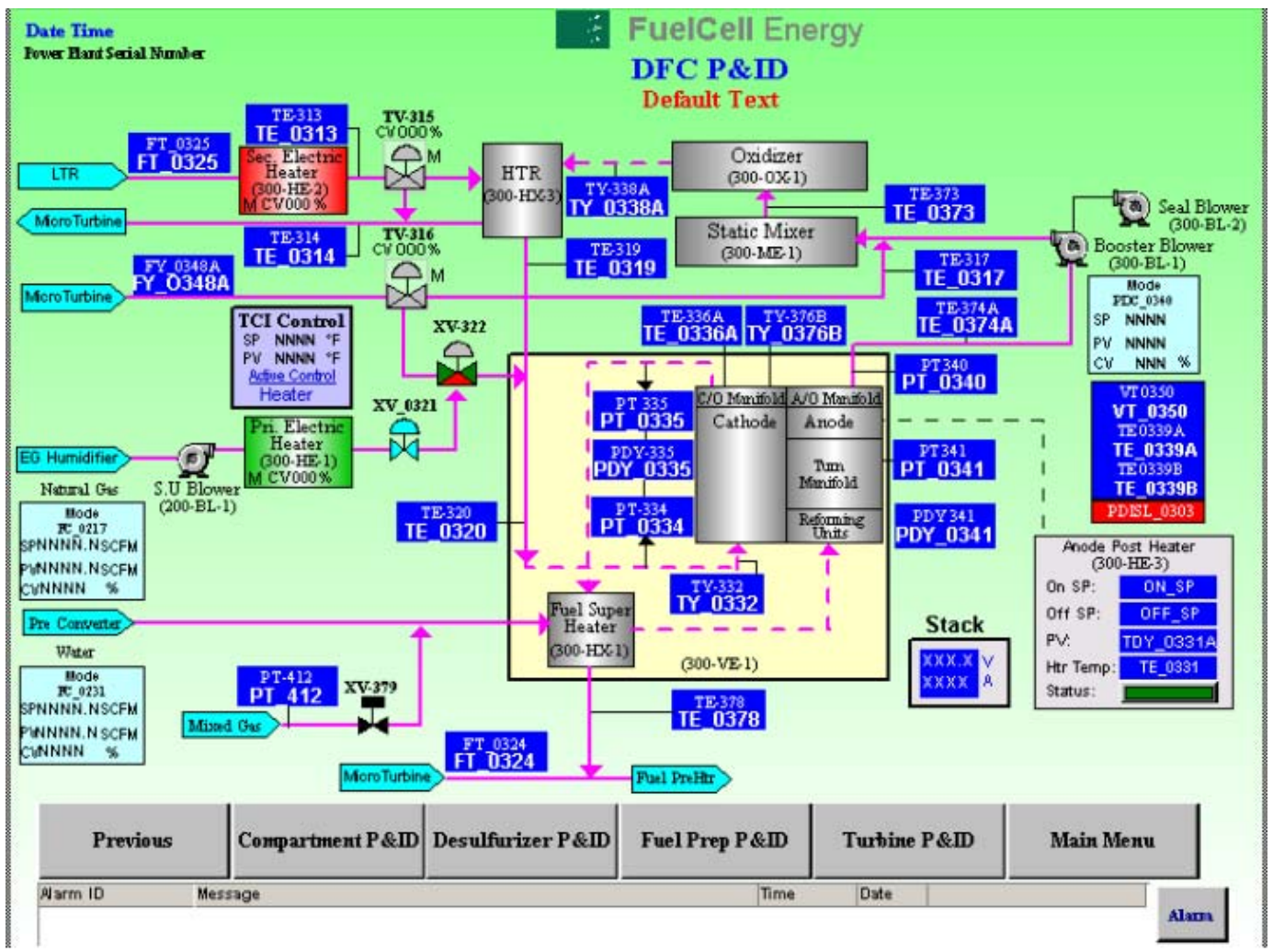

Figure 4. HMI Screen for DFC Module P\&ID 
Contract No. DE-FC26-00NT40798

Direct FuelCell/Turbine Power Plant

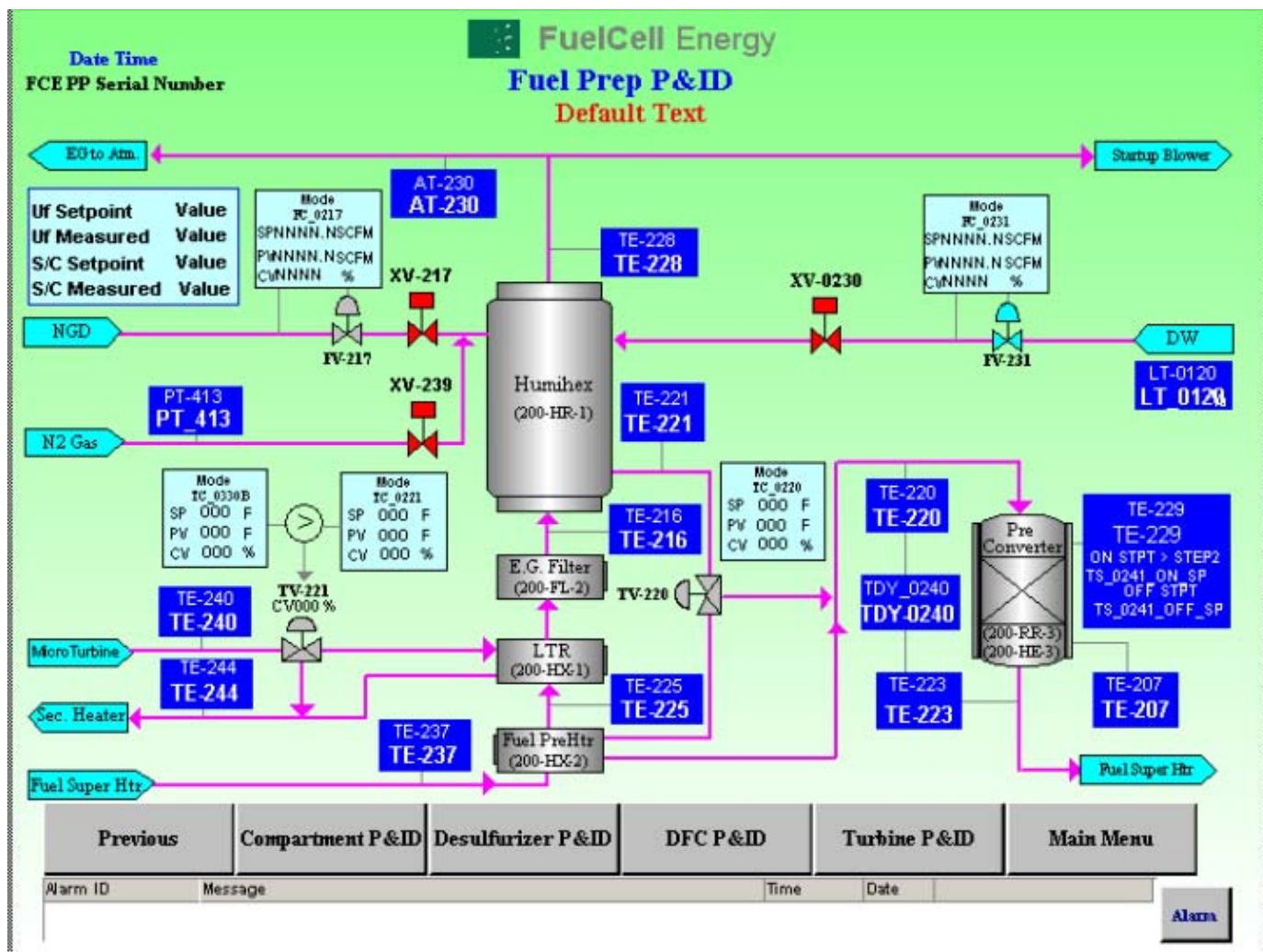

Figure 5. HMI Screen for Fuel Preparation P\&ID

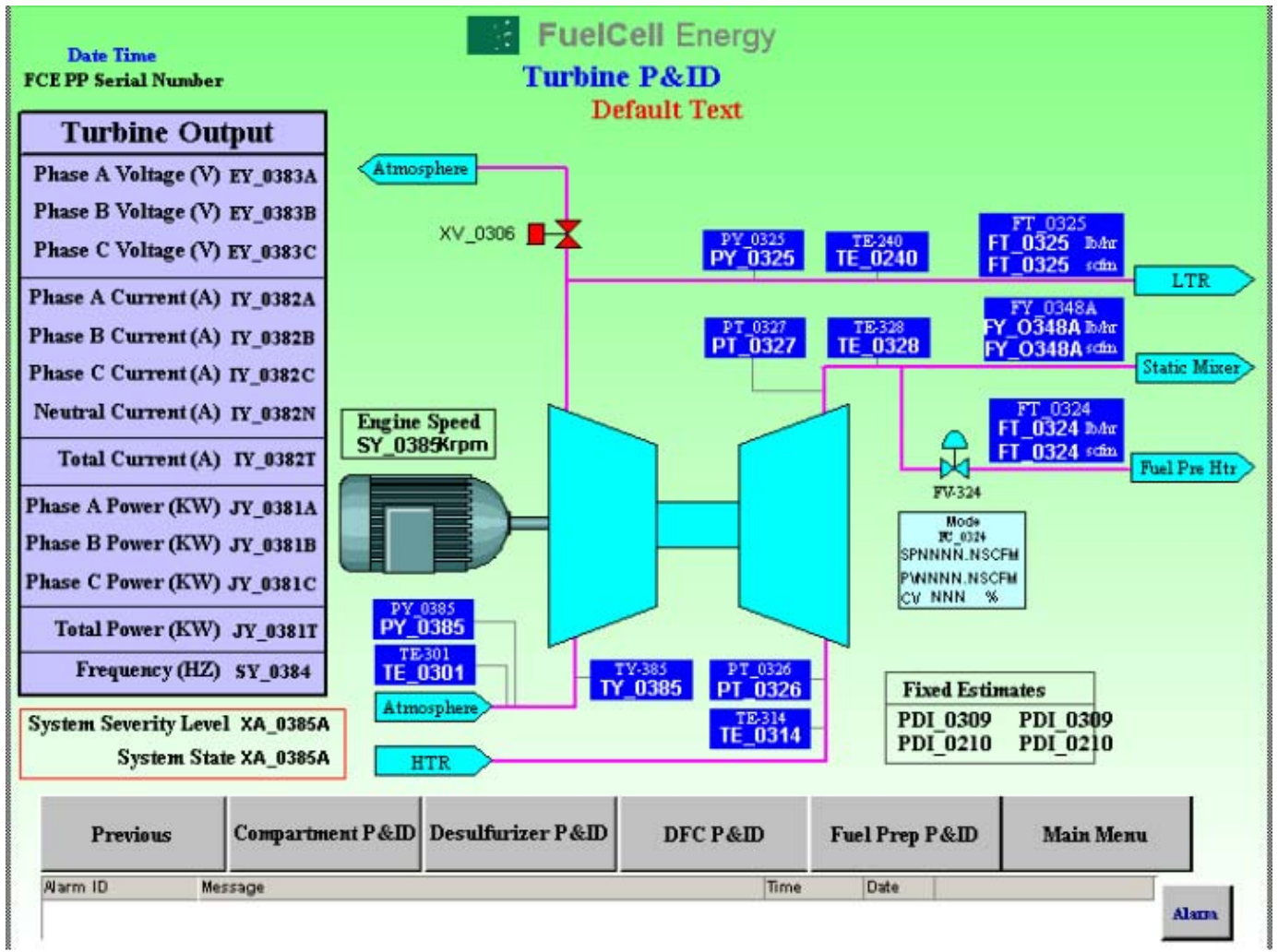

Figure 6. HMI Screen for Turbine P\&ID 


\subsection{CONCLUSION}

The design of the packaged sub-MW hybrid unit (for alpha demonstration) has made significant progress and has moved into the fabrication phase. Design modifications to the existing DFC-300A fuel cell module for its application to the DFC300/T unit were successfully tested. Fabrication of the structural steel skids was completed. Installation of equipment, piping, insulation, instrumentation, and electrical components was initiated.

\subsection{REFERENCES}

None. 